\title{
Nursing care for hematopoietic stem cell transplant recipients and their families
}

\author{
Cuidados de enfermagem direcionados aos transplantados com células-tronco \\ hematopoéticas e suas famílias
}

Isabelle Campos de Azevedo ${ }^{1}$, Alexandra do Nascimento Cassiano ${ }^{1}$, Jovanka Bittencourt Leite de Carvalho ${ }^{1}$, Marcos Antonio Ferreira Júnior ${ }^{1}$

Objective: to identify nursing care for hematopoietic stem cell transplant recipients and their families. Methods: integrative review with searches in the databases SCOPUS; National Library of Medicine; Web of Science, Cumulative Index to Nursing and Allied Heath Literature and Latin American and Caribbean Literature in Health Sciences. The selected studies were published between 2008 and 2014. Results: 460 articles were initially identified, culminating in the final sample of seven studies analyzed in their entirety. Care provided varied in all studies, from actions directed to health education practices, to the accomplishment of complementary therapies and the implementation of Advanced Nursing Practice with a view to qualification of care. Conclusion: care provided includes health education actions, complementary therapies to promote well-being and quality of life, as well as the implementation of the Advanced Nursing Practice with a view to qualification of care.

Descriptors: Nursing Care; Nursing; Family; Hematopoietic Stem Cell Transplantation.

Objetivo: identificar os cuidados de enfermagem direcionados aos transplantados com células-tronco hematopoéticas e suas famílias. Métodos: revisão integrativa com buscas nas bases de dados SCOPUS; National Library of Medicine; Web of Science, Cumulative Index to Nursisng and Allied Heath Literature e Literatura Latino-Americana e do Caribe em Ciências da Saúde. Os estudos selecionados foram publicados entre 2008 e 2014. Resultados: foram identificados inicialmente 460 artigos, que culminaram na amostra final de sete estudos analisados na íntegra. Os cuidados variaram em todos os estudos desde ações direcionadas à prática de educação em saúde, a realização de terapias complementares e a implementação da Prática Avançada em Enfermagem com vistas à qualificação do cuidado. Conclusão: os cuidados compreendem as ações de educação em saúde, a realização de terapias complementares para promoção do bem-estar e qualidade de vida, bem como, a implementação da Prática Avançada de Enfermagem com vistas à qualificação do cuidado.

Descritores: Cuidados de Enfermagem; Enfermagem; Família; Transplante de Celúlas-Tronco Hematopoéticas.

${ }^{1}$ Universidade Federal do Rio Grande do Norte. Natal, RN, Brazil.

Corresponding author: Isabelle Campos de Azevedo

Universidade Federal do Rio Grande do Norte, Departamento de Enfermagem. Avenida Salgado Filho, S/N, Lagoa Nova, CEP: $59078-970$.

Natal, RN, Brazil. E-mail: isabellebr2511@gmail.com 


\section{Introduction}

Hematopoietic stem cell transplantation is an aggressive therapeutic option for a set of genetically inherited or acquired onco-hematological and immunological diseases. This type of transplantation deals with intravenous infusion of hematopoietic progenitor cells to restore the medullary and immunological function of the affected patients. Hematopoietic progenitor cells used in transplantation can be obtained from bone marrow, peripheral blood, or placental and umbilical cord blood ${ }^{(1-2)}$.

Hematopoietic stem cell transplants are classified as autologous, when stem cells are from the patient him/herself; as allogeneic, when stem cells are from donors with compatible Human Histocompatibility Antigen, either they are related or not with the recipients; and syngeneic, when stem cells are from identical twin. This procedure has the purpose of restoring the medullary and immunological function of patients affected by some onco-hematological or immunological impairment, with possibility of cure or increase of disease-free survival ${ }^{(3)}$.

Each year, approximately 50,000 people undergo hematopoietic stem cell transplantation worldwide. Advances in this procedure techniques and nursing care can lead to progressive improvements in the survival of transplant recipients. With increased survival after transplantation, the risk of developing late complications increases substantially, such as graft versus host disease, which causes dermatological, gastrointestinal, ophthalmologic and respiratory morbidities, among others. These conditions may require different attention and care from the nursing team, the patient and their relatives and caregivers. These morbidities may impair quality of life or contribute to mortality of hematopoietic stem cell transplant recipients ${ }^{(4-5)}$.

During the stages of hematopoietic stem cell transplantation, patients and their families experience moments of anxiety, anguish and uncertainties that interfere with their daily lives. Especially in the period after hematopoietic stem cell transplantation, hospi- tal discharge affects the emotions of the subjects involved, since it will require re-adaptation of patients regarding their daily routine, besides the possibility of recurrence of the disease and the appearance of complications related to drug toxicity or even graft versus host disease. In this context, nursing plays an important role in guiding and training patients, families and caregivers in implementing care that helps and improves the quality of life of all involved ${ }^{(6-7)}$.

The nurse-patient-family relationship is very close when compared to other professionals involved in the process of hematopoietic stem cell transplantation, which leads to a greater responsibility for actions, therapeutic plans and instruction for care during hospitalization and especially after discharge. Thus, it is essential that nursing understands the specificities of all stages of hematopoietic stem cell transplantation $^{(8)}$.

Research on nursing care targeted at transplant recipients, as well as their relatives and caregivers, may contribute substantially to the work process of professionals working in this area and to the quality of life of the subjects involved in this context, with possibility of support for the construction of interventions that meet the health needs presented during the various phases of treatment.

Therefore, considering the difficulties faced by patients submitted to hematopoietic stem cell transplant and their relatives regarding care and coping strategies during all stages of transplantation, the objective of this study was to identify the nursing care targeted at hematopoietic stem cell transplant recipients together with and their families.

\section{Methods}

This is an integrative literature review, which is defined as a specific method that allows synthesizing and evaluating scientific evidence available in the literature in order to better understand a given research problem $^{(9-10)}$.

In order to give this study a scientific and criti- 
cal aspect, the following steps were performed: identification of the problem or research question; search in the literature, which included the definition of the inclusion and exclusion criteria of the articles; evaluation of data to define the information to be extracted from the selected articles; critical analysis of selected studies; and presentation of the review result ${ }^{(10)}$.

The present study was guided by the following question: what type of nursing care is provided to hematopoietic stem cell transplanted patients and their families?

The search in the literature occurred in June 2015, in pairs, using a proxy licensed by the Federal University of Rio Grande do Norte (www.capes.ufrn. br/porta 3128) in different computers, at the same time and same network through the following databases: SCOPUS, National Library of Medicine; Web of Science, Cumulative Index to Nursing and Allied Heath Literature and Latin American and Caribbean Literature in Health Sciences.

To search the databases, the following descriptors were used in the Descriptors in Health Sciences and Medical Subject Headings, respectively: 1\# (Transplante de Células-Tronco Hematopoéticas) and (Hematopoietic Stem Cell Transplantation); 2\# (Família) and (Family); 3\# (Cuidados de Enfermagem) and (Nursing Care). Crossings were performed using the Boolean operator AND, namely: 1 \# AND 2 \# AND 3 \#. In each database an uncontrolled search was carried out in order to identify studies that, due to indexation differences, could not be located with the use of the controlled descriptor.

In order to select the studies, the following inclusion criteria were adopted: complete articles available in the selected databases and addressing nursing care for patients submitted to Hematopoietic Stem Cell Transplantation and their families. Editorials, letters to the editor, abstracts, expert opinions, reviews, books, book chapters, theses and dissertations were excluded. There was no time cut or language limit.

of the 460 articles initially found, all were in- dexed in the National Library of Medicine and 34 of these were included in the first selection, which consisted of reading the titles and abstracts, as they presented some information about the studied theme. Thus, 23 were excluded because they did not address nursing care for the patient and the family/caregiver, and 11 were chosen to be read in full, of which four were excluded because they did not meet inclusion or exclusion or criteria, or because they did not answer the guiding question adopted. Thus, the final sample of this review was composed of seven out of the 11 studies selected for full reading, published between the years of 2008 and 2014.

During the search, the studies were pre-selected by means of a thorough reading of the titles and the abstracts to identify whether they are related to the guiding question of the review and to the inclusion and exclusion criteria adopted. Then, the articles were pre-selected by a couple of reviewers, in an independent manner. If there was disagreement among the reviewers, it was solved by consensus or by a third reviewer, if necessary. For the analysis and extraction of data, a script was elaborated with the following data: identification of the publication, place of study, methodological aspects, type of care. The strategy used to critically evaluate the studies was the identification of the level of evidence and the degree of recommendation.

The articles were classified according to the level of evidence, considering the research design of each study. Thus, they were classified as follows: I - those who presented evidence from systematic reviews or meta-analysis of relevant clinical trials; II - evidence derived from at least one well-designed controlled randomized clinical trial; III - well-delineated clinical trials without randomization; IV - well-designed cohort and case-control studies; V - systematic review of descriptive and qualitative studies; VI - evidence derived from a single descriptive or qualitative study; VII - opinion of authorities or expert committee report. The degrees of recommendation were classi- 
fied according to the levels of evidence, namely: Levels I and II (strong evidence); Levels III to V (moderate evidence); Levels VI and VII (weak evidence) ${ }^{(11)}$.

\section{Results}

Of the seven articles that composed the sample of this review, one was multi-centered (United States of America, Canada, Australia, Iceland, Ireland, Switzerland, South Korea and Saudi Arabia) ${ }^{(12)}$ and six were conducted only in the United States of America ${ }^{(13-18)}$; all were in the English language ${ }^{(12-18)}$, and only two have been published in the last five ye$\operatorname{ars}^{(17-18)}$

Figure 1 highlights the method used to base the studies, the level of evidence, the degree of recommendation and the care provided to the patients submitted to hematopoietic stem cell transplantation and to their relatives.

\begin{tabular}{|c|c|c|c|}
\hline Code & Method & $\begin{array}{l}\text { Level of evidence/ } \\
\text { Degree of recom- } \\
\text { mendation }\end{array}$ & Type of care provided to the patient and family \\
\hline 1 & Case study & VI/Weak & $\begin{array}{l}\text { Implementation of the Advanced Nursing Practice with patient submitted to } \\
\text { allogeneic hematopoietic stem cell transplantation and caregiver }{ }^{(12)} \text {. }\end{array}$ \\
\hline 2 & Cross-sectional study & VI/ Weak & $\begin{array}{l}\text { Health education with patients, relatives and caregivers at all stages of } \\
\text { hematopoietic stem cell transplantation }{ }^{(13)} \text {. }\end{array}$ \\
\hline 3 & Cross-sectional study & VI/ Weak & $\begin{array}{l}\text { Online discussion groups were held with family members and caregivers of } \\
\text { pediatric hematopoietic stem cell transplant recipients and health professionals } \\
\text { to identify problems affecting the family during this process }{ }^{(14)} \text {. }\end{array}$ \\
\hline 4 & Cohort study & IV/Moderate & $\begin{array}{l}\text { Intervention with couples of patients and family members on problem-solving } \\
\text { education during allogeneic transplantation }{ }^{(15)} \text {. }\end{array}$ \\
\hline 5 & $\begin{array}{l}\text { Qualitative descriptive } \\
\text { study }\end{array}$ & VI/ Weak & $\begin{array}{l}\text { Development of a health-related website for parents of children who had } \\
\text { undergone hematopoietic stem cell transplantation - Comprehensive Health } \\
\text { Enhancement Support System }{ }^{(16)} \text {. }\end{array}$ \\
\hline 6 & $\begin{array}{l}\text { Qualitative descriptive } \\
\text { study }\end{array}$ & VI/ Weak & $\begin{array}{l}\text { Implementation and intervention with therapeutic massage and acupressure } \\
\text { performed by parents in children submitted to hematopoietic stem cell } \\
\text { transplantation }{ }^{(17)} \text {. }\end{array}$ \\
\hline 7 & Randomized clinical trial & II/Strong & Therapeutic intervention with a music video ${ }^{(18)}$. \\
\hline
\end{tabular}

Figure 1 - Characterization of the articles according to the method, level of evidence/degree of recommendation and type of care provided to the patient and his/her family

\section{Discussion}

A limitation of this study was the scarcity of articles on nursing care for hematopoietic stem cell transplant recipients and their relatives/caregivers, which may be associated with the use of only one crossing composed of three descriptors and which limited the retrieval of the articles researched. The use of uncontrolled search for the investigation in the databases did not influence significantly the sample size, since this method extends the search for relevant studies approaching the subject.
In the studies, health education was conducted through techniques such as educational sessions and technological tools, for example, informative website and online discussion groups. These actions were aimed at patients, relatives and caregivers during the transplantation process, mainly in the postoperative period $^{(13-15)}$.

Hematopoietic stem cell transplantation exposes the patient and his/her family to physical and psychological stressors, such as changes in the routine, prolonged hospitalization, side effects of the treatment, loss of motivation, fear of death, difficulty in 
performing daily activities and in social interaction, adjustment disorders, among others ${ }^{(19-20)}$.

Parallel to hematopoietic stem cell transplantation, the use of complementary and integrative therapies to promote the well-being of transplanted patients and their families appears as a strategy for qualification and humanization of care. Among the various techniques of therapy, massage therapy and music therapy were mentioned in the selected stu$\operatorname{dies}^{(17-18)}$. Nowadays, there has been a growing demand for complementary therapies in order to overcome the biomedical-technical model, so that the patient can feel relaxed, supported, experience well-being, internal strength and cope with the disease ${ }^{(21)}$.

There are several techniques for promoting health in the corpus of complementary and integrative therapies which, although recognized by popular knowledge since ancient times, have not still been integrated to most official health programs, especially in Western countries. Among other forms of health care, we can mention acupuncture, aromatherapy, anthroposophy, auricular therapy, phytotherapy, hydrotherapy, iridology, meditation, chiropractic, reiki, reflexology, relaxation, floral therapy and therapeutic touch ${ }^{(22)}$.

Because of its proximity and perception of objective and subjective needs of patients, nursing has the possibility of offering complementary alternatives for treatment, provided that they are based on research that certifies the safety and benefits of the suggested practice ${ }^{(23)}$. In Brazil, the Federal Nursing Council establishes and recognizes Alternative Therapies as a specialty or qualification of the Nursing professional, who, in order to receive this degree, must have completed and been approved in a course offered by a recognized teaching institution or a similar entity, with a minimum course load of 360 hours $^{(24)}$.

In the same way, massage therapy was referenced as an instrument capable of mediating nursing performance in the promotion of care between parents and children. The use of massage therapy dates back to ancient medical practices, and its beneficial effects have also been evidenced by improvements in children's motor and sensory behavior ${ }^{(17,25)}$.

The contact promoted by this technique favors the relief of pain, nausea, anxiety and fatigue, besides favoring relaxation to hospitalized children during the treatment. Among the benefits, the improvement of communication between family and child, and promotion of well-being and trust between both are also mentioned $^{(17,25)}$.

Psychosocial support strategies are also crucial during the transplantation process, as they improve coping responses to difficulties and promote quality of life ${ }^{(18)}$. This is a strategy that promotes family rehabilitation and understands that light relational technologies are important for the production of care in the psychosocial care of patients undergoing hematopoietic stem cell transplantation ${ }^{(26)}$.

On this subject, a study carried out with transplanted adolescents and young people showed that group therapy among patients, relatives and caregivers improved social and family interaction; promoted a brave confrontation of the difficulties encountered during the hematopoietic stem cell transplantation process; enabled reflection on the experiences; and reduced the feelings of suffering ${ }^{(18)}$.

Among the articles analyzed in this study, the use of Advanced Nursing Practice as a guiding methodology for nursing actions is highlighted, which can be applied in several areas of knowledge, such as the care of patients with hematopoietic stem cell transplantation.

The Advanced Nursing Practice is used as an instrument for the implementation of educational actions, composed of six core competences, which are: 1) Expert coaching and guidance: ability to adapt educational interventions based on the individual's and the family's needs; 2) Consultation: use of multidisciplinary care in order to enhance the educational intervention; 3) Research Skills: research practice in nursing, in order to support actions in scientific evidence; 4) Clinical and professional leadership: ability to interact with the team and to implement planned actions; 5) Collaboration: accomplishing partnerships 
with professionals of other services for the benefit of the patient; and 6) Ethical Decision-Making skills: preservation of ethical considerations regarding patient care $^{(12)}$.

The experience reported with the use of Advanced Nursing Practice in the care of transplant patients and their families reinforced the importance of educational actions for the moment of discharge, given the complexity involved in post-treatment care. Such guidelines can cause improvements in quality of life and reduction of morbidity ${ }^{(12)}$.

Therefore, the nurse must work decisively in the care directed to hematopoietic stem cell transplanted patients and especially to their relatives. This assumption requires the professional to build knowledge, skills and attitudes accumulated during the training period and professional experience ${ }^{(27)}$.

The results addressed by this study may contribute significantly as a base for the improvement and applicability of nursing care to hematopoietic stem cell transplanted patients, considering the importance of the constant qualification of praxis, which should be based on scientific evidence that best meet the health needs of each patient.

\section{Conclusion}

Nursing care aimed at hematopoietic stem cell transplanted patients and their families includes actions aimed at problem-solving health education, at the accomplishment of complementary therapies to promote the well-being and quality of life of these patients, as well as, at the implementation of Advanced Nursing Practice with a view to qualifying the care provided.

Nursing care in this field of health care aims to provide quality of life, greater survival and comprehensive assistance to the subjects involved. Thus, when nursing care is targeted at the real needs of patients, it shows to be more effective for the control of signs and symptoms resulting from the transplant process and, in relation to health education practices, it provides knowledge that goes from the clarification of doubts related to the clinic of the disease to nutritional care, hygiene and importance of continuing the treatment.

\section{Acknowledgements}

We thank to the Coordenação de Aperfeiçoamento de Pessoal de Nível Superior, for the scholarship granted.

\section{Collaborations}

Azevedo IC and Cassiano AN contributed to the conception and design, analysis and interpretation of the data, essay writing and critical review of the intellectual content. Carvalho JBL and Ferreira Júnior MA approved the final version to be published.

\section{Referências}

1. Ministério da Saúde (BR). Portaria ${ }^{\circ} 931$ de 2 de maio de 2006. Aprova o Regulamento Técnico para Transplante de Células-Tronco Hematopoéticas. Brasília: Ministério da Saúde; 2006.

2. Henig I, Zuckerman T. Hematopoietic stem cell transplantation-50 years of evolution and future perspectives. Rambam Maimonides Med J. 2014; 5(4):1-15. doi: http://dx.doi.org/10.5041/ RMMJ.10162

3. Santos CLT, Sawada NO, Santos JLF. Evaluation of the health-related quality of life of hematopoietic stem cell transplantation patients. Rev Latino-Am Enfermagem. 2011; 19(6):1322-8. doi: http:// dx.doi.org/10.1590/S0104-11692011000600007

4. Majhail NS, Bajorunaite R, Lazarus HM, Wang Z, Klein JP, Zhang MJ, et al. Long-term survival and late relapse in 2-year survivors of autologous haematopoietic cell transplantation for Hodgkin and non-Hodgkin lymphoma. Br J Haematol. 2009; 147(1):129-39. doi: http://dx.doi.org/10.1111/ j.1365-2141.2009.07798.x 
5. Majhail NS, Rizzo JD. Surviving the cure: long term followup of hematopoietic cell transplant recipients. Bone Marrow Transplant. 2013; 48:114551. doi: http://dx.doi.org/10.1038/bmt.2012.258

6. Costanzo ES, Juckett MB, Coe CL. Biobehavioral influences on recovery following hematopoietic stem cell transplantation. Brain Behav Immun. 2013; 30(Suppl):68-74. doi: http://dx.doi. org/10.1016/j.bbi.2012.07.005

7. Lima K, Bernardino E. Nursing care in a hematopoietic stem cells transplantation unit. Texto Contexto Enferm. 2014; 23(4):845-53. doi: http:// dx.doi.org/10.1590/0104-07072014000440013

8. Guimarães CS, Silveira RCCP, Nilsen L, Rodrigues MCO. Transplante autólogo de células-tronco hematopoéticas para esclerose sistêmica: ações de enfermagem. Rev Eletr Enf [Internet]. 2014 [citado 2017 jun 13]; 16(1):77-83. Disponível em: http://dx.doi.org/10.5216/ree.v16i1.20962

9. Broome ME. Integrative literature reviews for the development of concepts. In: Rodgers BL, Knafl KA. Concept development in Nursing. Philadelphia (PA): W. B. Saunders Company; 1993. p.231-50.

10. Whittemore R, Knafl K. The integrative review: updated methodology. J Adv Nurs. 2005; 52(5):54653. doi: http://dx.doi.org/10.1111/j.13652648.2005.03621. $x_{-}$

11. Melnyk BM, Fineout-Overholt E, Stillwell SB, Williamson KM. Evidence-based practice: step by step. Am J Nurs. 2010; 110(5):51-3. doi: http:// dx.doi.org/10.1097/01.NAJ.0000366056.06605. $\mathrm{d} 2$

12. Bevans M, Tierney K, Bruch C, Burgunder M, Castro K, Ford R, et al. Hematopoietic stem cell transplantation nursing: a practice variation study. Oncol Nurs Forum. 2009; 36(6):17-25. doi: http://dx.doi.org/10.1188/09.0NF.E317-E325

13. Cooke L, Gemmil R, Grant M. APN core competencies: a framework for developing and testing an APN discharge intervention. Clin Nurse Spec. 2008; 22(5):218-25. doi: http://dx.doi. org/10.1097/01.NUR.0000325366.15927.2d

14. Mayer DK, Tighiouart H, Terrin N, Stewart S, Peterson E, Jeruss S, et al. A brief report of caregiver needs and resource utilization during pediatric hematopoietic stem cell transplantation. J Pediatr Oncol Nurs. 2009; 26(4):223-9. doi: http://dx.doi.org/10.1177/1043454209340409
15. Bevans M, Castro K, Prince P, Shelburne N, Prachenko O, Loscalzo M, et al. An individualized dyadic problem-solving education intervention for patients and family caregivers during allogeneic HSCT: a feasibility study. Cancer Nurs. 2010; 33(2):24-32. doi: http://dx.doi.org/10.1097/ NCC.0b013e3181be5e6d

16. Mayer DK, Ratichek S, Berhe H, Stewart S, McTavish F, Gustafson D, et al. Development of a healthrelated website for parents of children receiving hematopoietic stem cell transplant: HSCT-CHESS. J Cancer Surviv. 2010; 4(1):67-73. doi: http:// dx.doi.org/10.1007/s11764-009-0108-z

17. Ackerman SL, Lown EA, Dvorak CC, Dunn EA, Abrams DI, Horn BN, et al. Massage for children under going hematopoietic cell transplantation: a qualitative report. Evid Based Complement Alternat Med. 2012; (2012):1-9. doi: http:// dx.doi.org/10.1155/2012/792042

18. Robb SL, Burns DS, Stegenga KA, Haut PR, Monahan PO, Meza J, et al. Randomized clinical trial of therapeutic music video intervention for resilience outcomes in adolescents/young adults undergoing hematopoietic stem cell transplant: a report from the Children's Oncology Group. Cancer. 2014; 120(6):909-17. doi: http://dx.doi. org/10.1002/cncr.28355

19. Sanches MVP, Nascimento LC, Lima RAG. Crianças e adolescentes com câncer em cuidados paliativos: experiência de familiares. Rev Bras Enferm. 2014; 67(1):28-35. doi: http://dx.doi. org/10.5935/0034-7167.20140003

20. Alves RP, Oliveira-Cardoso É, Mastropietro AP, Voltarelli JC, Santos MA. Transplante de célulastronco hematopoéticas e qualidade de vida após alta hospitalar. Psic Saúde Doenç [Internet]. 2012 [citado 2016 dez 22]; 13(1):87-99. Disponível em: http://www.scielo.mec.pt/pdf/psd/v13n1/ v13n1a08.pdf

21. Fernández-Cervilla $\mathrm{AB}$, Piris-Dorado AI, CabrerVives ME, Barquero-González A. Current status of complementary therapies in Spain in nursing degree. Rev Latino-Am Enfermagem. 2013; 21(3):679-86. doi: http://dx.doi.org/10.1590/ S0104-11692013000300005 
22. Nagai SC, Queiroz MS. Medicina complementar e alternativa na rede básica de serviços de saúde: uma aproximação qualitativa. Ciênc Saúde Coletiva. 2011;16(3):1793-800. doi: http://dx.doi. org/10.1590/S1413-81232011000300015

23. Freitag VL, Andrade A, Rossato BM. O Reiki como forma terapêutica no cuidado à saúde: uma revisão narrativa de literatura. Enfermería Glob. 2015; 38(2):346-56. doi: http://dx.doi.org/10.6018/ eglobal.14.2.200511

24. Conselho Federal de Enfermagem. Resolução $\mathrm{n}^{\circ}$ 197, de 19 de março de 1997. Estabelece e reconhece as terapias alternativas como especialidade e/ou qualificação do profissional de Enfermagem. Rio de Janeiro: COFEN; 1997.
25. Barbosa KC, Sato SN, Alves EGR, Fonseca ALA, Fonseca FLA, Junqueira VBC, et al. Efeitos da Shantala na interação entre mãe e criança com síndrome de down. Rev Bras Crescimento Desenvolvimento Hum. 2011; 21(2):356-61. doi: http://dx.doi.org/10.7322/jhgd.20023

26. Mielke FB, Kohlrausch E, Olschowsky A, Schneider JF. A inclusão da família na atenção psicossocial: uma reflexão. Rev Eletr Enf [Internet]. 2010 [citado $2016 \mathrm{dez} 20$ ]; 12(4):761-5. Disponível em: http://dx.doi.org/10.5216/ree.v12i4.6812

27. Lima K, Bernardino E, Wolff LDG, Peres AM. Características da produção científica de enfermagem acerca de transplante de célulastronco hematopoiéticas. Cogitare Enferm. 2012; 17(3):568-73. doi: http://dx.doi.org/10.5380/ ce.v17i3.21274 